\title{
GEEN AARDVERSCHUIVING ZONDER INCIDENTEN
}

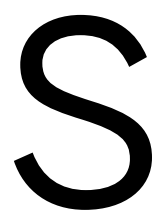
oms moet de chaos compleet zijn voordat een complex systeem als de zorg uit een bestaand evenwicht wordt getrokken om een nieuw evenwicht te kunnen bereiken. Dat inzicht van veranderkundige Thijs Homan zou wel eens op kunnen gaan voor de meervoudige transitie waaraan de zorg en het sociale domein onderhevig zijn.

Gemeenten proberen hun nieuwe hoofdtaak in het sociale domein te omarmen. Een ontwikkeling die Hoogleraar Inkoopmanagement Jan Telgen en co-auteurs in het essay vanaf pagina 59 typeren als 'een ware aardverschuiving'.

Die aardverschuiving pakt voor zorgaanbieders gevaarlijk uit: ze verliezen budgettaire zekerheden en moeten competitie aangaan met soortgenoten. En die "noodgedwongen beweging van de logica van de hiërarchie naar de logica van het netwerk", zoals organisatiekundige Wilfrid Opheij het uitdrukt in het omslagverhaal (p. 14), valt bestuurders zwaar. Talrijk zijn de bestuurders en toezicht houders die denken dat het hun tijd wel zal duren. In vette jaren heeft de organisatie immers een fors eigen vermogen opgebouwd. Bij alle hoorbare decentralisatiegeweld klinkt dat wonderlijk in de oren, om niet te zeggen verontrustend. Want in de praktijk zal deze beweging heus tot betere zorg moeten leiden voor minder
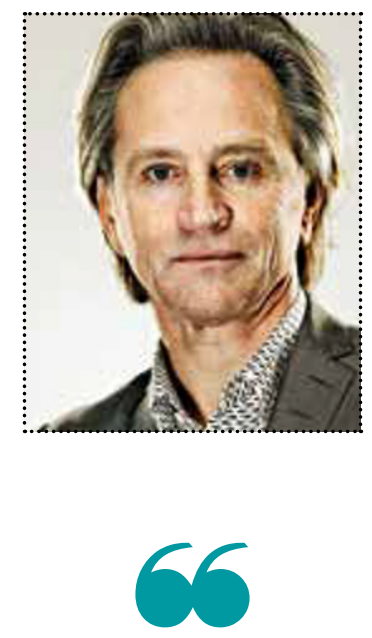<smiles>[Mg][Mg]</smiles>
VERSCHUVING PAKT VOOR ZORGAANBIEDERS GEVAARLIJKUTT

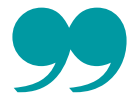

geld. Twee voorbeelden uit de recente geschiedenis bewijzen dat dat mogelijk is: $\mathrm{Na}$ ingrijpende maatregelen en een forse ontslaggolf boekt de Amsterdamse Jeugdbescherming opmerkelijk betere resultaten dan voorheen. Voor ongeveer de helft van de kosten. En Arduin in Zeeland heeft al in de jaren ' 90 een ingrijpende omslag gemaakt op de puinhopen van de intramurale instelling Vijvervreugd. Sindsdien maken Zeeuwen met een verstandelijk beperking 'gewoon' deel uit van de samenleving. Ze genieten een aantoonbare betere kwaliteit van leven. En Arduin heeft als voordeel dat er geen instellingsvastgoed als een molensteen om de nek hangt.

Het kan dus, maar het komt niet vanzelf. Tussen nu en de invoering van de decentralisaties zullen er zeker incidenten zijn, zo erkent staatssecretaris Martin van Rijn (p. 22 ). Zelf kreeg hij er onlangs in Nieuwsuur weer een voor de kiezen. De term 'wenswachtenden' kan in het woordenboek en Van Rijn mocht opdraven in een spoeddebat, waar hij de opwinding overigens weer opmerkelijk vlot wist te neutraliseren. Want deze staatssecretaris gaat voor de hoofdprijs: “Laten we eerlijk zijn, deze verandering voltrekt zich niet op 1 januari 2015. Dan begint het pas."

\section{Ruud Koolen}

hoofdredacteur Lucide 